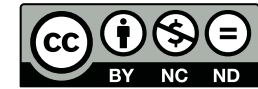

Estudos Teológicos foi licenciado com uma Licença Creative Commons Atribuição - NãoComercial - SemDerivados 3.0 Não Adaptada

http://dx.doi.org/10.22351/et.v58i1.3284

\title{
O estranho caso do Ensino Religioso: CONTRADIÇÕES LEGAIS E QUESTÕES EPISTEMOLÓGICAS ${ }^{1}$
}

\author{
The strange case of Religious Education: \\ Legal contradictions and epistemological issues
}

Claudete Beise Ulrich ${ }^{2}$ José Mario Gonçalves ${ }^{3}$

\begin{abstract}
Resumo: O Ensino Religioso permanece sendo campo de acalorados debates. A polêmica em torno da pertinência de sua oferta nas escolas públicas, bem como a respeito da sua natureza e finalidade se refletem na legislação, cujas lacunas deixam margem para interpretações ambíguas e contraditórias. A ausência de clareza revela-se também na confusão a respeito de sua identidade epistemológica, que também é matéria de disputa. Neste artigo, tratamos de ambas as questões: a legal e a epistêmica, procurando refletir sobre o status atual desses debates.
\end{abstract}

Palavras-chave: Ensino Religioso. Legislação. Epistemologia.

Abstract: Religious Education remains a field of heated debate. The controversy over the relevance of its offer in public schools, as well as its nature and purpose are reflected in legislation, whose gaps leave room for ambiguous and contradictory interpretations. The absence of clarity also reveals itself in the confusion about its epistemological identity, which is also a matter of dispute. In this article, we address both the legal and the epistemic issues, seeking to reflect on the current status of these debates.

Keywords: Religious Education. Legislation. Epistemology.

1 O artigo foi recebido em 30 de março de 2018 e aprovado em 17 de maio de 2018 com base nas avaliações dos pareceristas ad hoc.

2 Doutora em Teologia (EST - São Leopoldo/RS), pós-doutorado em História (UFSC - Florianópolis) e pós-doutoranda em Educação (UFES - Vitória/ES). Professora do Programa de Pós-Graduação em Ciências das Religiões na Faculdade Unida de Vitória (FUV - Vitória/ES). Coordenadora dos Grupos de Pesquisa Religião, Gênero, Violências: Direitos Humanos (REGEVI) e da Cátedra Unida de Teologia Pública e Estudos da Religião. Contato: claudete@faculdadeunida.com.br

3 Doutor em História (UFES - Vitória/ES). Professor do Programa de Pós-Graduação em Ciências das Religiões da Faculdade Unida de Vitória (FUV - Vitória/ES). Coordenador da pós-graduação Lato Sensu. Pesquisador do Grupo de Pesquisa Cátedra Unida de Teologia Pública e Estudos da Religião. Contato: mario@faculdadeunida.com.br 


\section{Introdução}

O Ensino Religioso continua sendo um espaço de disputa na educação brasileira. Foi elevado ao status de componente curricular no artigo 33 da Lei de Diretrizes e Bases da Educação Nacional - LDBEN (Lei 9.394/96), conforme a redação dada pela Lei 9.475/97, porém com obrigatoriedade para a escola e não para os/as estudantes. $\mathrm{O}$ Ensino Religioso consta como uma das áreas de conhecimento na atual Base Nacional Curricular Comum (BNCC) aprovada em 2018. No entanto, há contradições e impasses na legislação. Também não há clareza em relação às questões epistemológicas que envolvem a prática desse componente curricular nas escolas públicas brasileiras. $\mathrm{O}$ presente artigo reflete sobre o estranho caso do Ensino Religioso na educação brasileira, que se mostra nas contradições e nos impasses da própria legislação brasileira e na falta de clareza em relação às questões epistemológicas que envolvem esse componente curricular. A versão final da Base Nacional Comum Curricular, aprovada em 2018, afirmou que o objeto de estudo do Ensino Religioso deve ser produzido "no âmbito das diferentes áreas do conhecimento científico das Ciências Humanas e Sociais, notadamente da(s) Ciência(s) da(s) Religião(ões), sem privilegiar nenhuma crença ou convicção, considerando a pluralidade religiosa brasileira".

\section{Ensino Religioso: contradições e impasses na legislação}

O Ensino Religioso possui uma condição sui generis na legislação brasileira: é o único componente curricular explicitamente mencionada na Constituição Federal de 1988 e também é o único componente curricular do ensino fundamental que é de "matrícula facultativa" (Art. 210, $\S 1^{\circ}$ ). ${ }^{4}$ Essa especificidade também está descrita no artigo 33 Lei de Diretrizes e Bases da Educação Nacional - LDBEN (Lei 9.394/96), conforme a redação dada pela Lei 9.475/97:

Art. 33. O ensino religioso, de matrícula facultativa, é parte integrante da formação básica do cidadão e constitui disciplina dos horários normais das escolas públicas de ensino fundamental, assegurado o respeito à diversidade cultural religiosa do Brasil, vedadas quaisquer formas de proselitismo.

$\S 1^{\circ}$ Os sistemas de ensino regulamentarão os procedimentos para a definição dos conteúdos do ensino religioso e estabelecerão as normas para a habilitação e admissão dos professores.

$\S 2^{\circ}$ Os sistemas de ensino ouvirão entidade civil, constituída pelas diferentes denominações religiosas, para a definição dos conteúdos do ensino religioso. ${ }^{5}$

4 “O ensino religioso, de matrícula facultativa, constituirá disciplina dos horários normais das escolas públicas de ensino fundamental.” BRASIL. Constituição da República Federativa do Brasil. Brasília: Senado Federal, 1988.

5 BRASIL. Lei n ${ }^{\circ}$ 9.475, de 22 de julho de 1997. Dá nova redação ao art. 33 da Lei n 9.394, de 20 de dezembro de 1996, que estabelece as diretrizes e bases da educação nacional. Disponível em: <http:// www.planalto.gov.br/ccivil_03/leis/L9475.htm>. Acesso em: 10 mar. 2018. 
Além da matrícula facultativa, a LDBEN aponta algumas outras especificidades do Ensino Religioso: primeiro, o caput do artigo 33 tem a preocupação de proibir "quaisquer formas de proselitismo". Em segundo lugar, a lei delega aos sistemas de ensino a responsabilidade de definir conteúdos e de estabelecer regras de formação e admissão de docentes $\left(\S 1^{\circ}\right)$. Por fim, o mesmo artigo estabelece que os sistemas de ensino devem ouvir as opiniões das diferentes denominações religiosas na definição dos conteúdos desse componente curricular $\left(\S 2^{\circ}\right)$.

Tais especificidades têm contribuído para que a oferta do Ensino Religioso seja motivo de muitos conflitos. No que diz respeito ao fato desse componente curricular ser de oferta obrigatória, mas de matrícula facultativa, os sistemas de ensino diferem na forma como resolver o problema dos alunos que optam por não cursá-la: algumas redes ofertam atividades paralelas, enquanto outras estabelecem uma matriz curricular com mais de 800 horas anuais, de modo que garanta aos estudantes que optarem por não cursar esse componente curricular que cumpram o mínimo de horas-aula determinado pela legislação. ${ }^{6}$

Outra questão debatida diz respeito à questão do proselitismo e sua relação com o conceito de confessionalidade. A ressalva da LDBEN de que o componente curricular Ensino Religioso deve ser isento de proselitismo não se mostrou suficiente: o que se entende por proselitismo? Ele se distingue da confessionalidade? Em vários estados da Federação, pratica-se a modalidade confessional de Ensino Religioso, entendendo que ela não se confunde com proselitismo, por supostamente garantir que cada aluno participe de aulas condizentes com sua confissão religiosa ou que opte por não se matricular nesse componente curricular. Nesse tipo de oferta, os docentes são contratados de acordo com os diferentes credos dos alunos interessados. ${ }^{7}$ Um complicador dessa posição foi o acordo estabelecido em 2010 entre o Estado brasileiro e a Santa Sé, que reconhece em seu artigo 11, parágrafo $1^{\circ}$, que "o ensino religioso, católico e de outras confissões religiosas, de matrícula facultativa, constitui disciplina dos horários normais das escolas públicas de ensino fundamental, assegurado o respeito à diversidade cultural religiosa do Brasil, em conformidade com a Constituição e as outras leis vigentes, sem qualquer forma de discriminação".

Entendendo que o acordo era inconstitucional, a Procuradoria-Geral da República entrou com uma Ação Direta de Inconstitucionalidade (ADI) contra o referido artigo, solicitando ao Supremo Tribunal Federal (STF) que, em nome da laicidade do

6 Para uma breve apresentação de como as redes estaduais de ensino tentam resolver o assunto, veja-se JUNQUEIRA, Sérgio Rogério Azevedo; HOLANDA, Ângela Maria Ribeiro; CORRÊA, Rosa Lydia Teixeira. Ensino Religioso: aspectos legais. In: JUNQUEIRA, Sérgio Rogério Azevedo (Org.). Ensino Religioso no Brasil. Florianópolis: Insular, 2015. p. 30-32.

7 JUNQUEIRA; HOLANDA; CORREAA, 2015, p. 32-33.

8 BRASIL. Decreto $n^{\circ}$ 7.107, de 11 de fevereiro de 2010. Promulga o Acordo entre o Governo da República Federativa do Brasil e a Santa Sé relativo ao Estatuto Jurídico da Igreja Católica no Brasil, firmado na Cidade do Vaticano, em 13 de novembro de 2008. Disponível em: <http://www.planalto.gov.br/ ccivil_03/_ato2007-2010/2010/decreto/d7107.htm>. Acesso em: 10 mar. 2018. 
Estado, se posicione contra o Ensino Religioso confessional nas escolas públicas. ${ }^{9} \mathrm{Em}$ 27 de setembro de 2017, pelo placar de seis votos contra cinco, o STF considerou o pedido improcedente. ${ }^{10}$ Isso significa que, para o Supremo Tribunal Federal, o Ensino Religioso confessional nas escolas públicas é constitucional e não é idêntico à prática do proselitismo.

Já a atribuição que a Lei de Diretrizes e Bases dá aos estados e municípios de estabelecer os critérios de habilitação dos docentes para o Ensino Religioso precisa ser harmonizada com o artigo 62 da própria LDBEN, que determina a licenciatura plena como formação mínima para a atuação na educação básica. ${ }^{11}$ Dessa forma, cada rede estabelece seus próprios critérios de como cumprir essa legislação: em algumas, exige-se licenciatura em qualquer área, acrescida de algum tipo de formação complementar em Ensino Religioso; noutras, a área é suprida por professores com licenciatura na área das humanidades; noutras ainda, há previsão de licenciados em Ciência(s) da(s) Religião(ões), e há também redes que admitem alunos com formação em Teologia, embora existam somente bacharelados nessa área, o que contraria o artigo da LDBEN supracitado. ${ }^{12}$

Em relação ao conteúdo do componente curricular Ensino Religioso, não há previsão de diretrizes curriculares nacionais, como acontece com outros componentes curriculares do ensino fundamental. ${ }^{13}$ Ao determinar que os sistemas de ensino devem ouvir "entidade civil, constituída pelas diferentes denominações religiosas, para a definição dos conteúdos do ensino religioso", a legislação não somente abre mão de estabelecer parâmetros curriculares nacionais para esse componente curricular, como abre um precedente para a interpretação confessional da legislação, como se faz em várias redes e como, por fim, entendeu o STF.

9 BRASIL. Supremo Tribunal Federal. Ação direta de inconstitucionalidade $n^{\circ}$ 4439/DF - Distrito Federal. Relator: Ministro Roberto Barroso. Petição inicial, 30 jul. 2010. Disponível em: <http:// redir.stf.jus.br/estfvisualizadorpub/jsp/consultarprocessoeletronico/ConsultarProcessoEletronico. jsf? seqobjetoincidente=3926392 >. Acesso em: 10 mar. 2018 .

10 BRASIL. Supremo Tribunal Federal. Ação direta de inconstitucionalidade no 4439/DF - Distrito Federal. Relator: Ministro Roberto Barroso. Certidão de Julgamento, 27 set. 2017. Disponível em: < http://redir. stf.jus.br/estfvisualizadorpub/jsp/consultarprocessoeletronico/ConsultarProcessoEletronico.jsf?seqobjet oincidente $=3926392>$. Acesso em: 10 mar. 2018.

11 BRASIL. Lei ${ }^{\circ}$ 13.415, de 16 de fevereiro de 2017. Altera as Leis nos 9.394, de 20 de dezembro de 1996, que estabelece as diretrizes e bases da educação nacional, e 11.494, de 20 de junho 2007, que regulamenta o Fundo de Manutenção e Desenvolvimento da Educação Básica e de Valorização dos Profissionais da Educação, a Consolidação das Leis do Trabalho - CLT, aprovada pelo Decreto-Lei no 5.452, de $1^{\circ}$ de maio de 1943, e o Decreto-Lei n ${ }^{\circ} 236$, de 28 de fevereiro de 1967; revoga a Lei n$^{\circ} 11.161$, de 5 de agosto de 2005; e institui a Política de Fomento à Implementação de Escolas de Ensino Médio em Tempo Integral. Disponível em: <http:/www.planalto.gov.br/ccivil_03/_Ato2015-2018/2017/Lei/L13415.htm\#art7>. Acesso em: 10 mar. 2018.

12 Sobre os critérios adotados pelos estados e municípios no tocante à formação de docentes para o Ensino Religioso, veja-se JUNQUEIRA; HOLANDA; CORRÊA, 2015, p. 46-55.

13 Os Parâmetros Curriculares Nacionais do Ensino Religioso (São Paulo: Ave Maria, 1997), embora sejam utilizados por várias redes de educação, não foram elaborados no âmbito do MEC, mas por uma entidade da sociedade civil, o FONAPER (Fórum Nacional Permanente do Ensino Religioso). 
Esse quesito ensejou o grande debate em torno da presença do componente curricular Ensino Religioso na Base Nacional Comum Curricular (BNCC). ${ }^{14} \mathrm{Na}$ primeira versão da BNCC, o Ensino Religioso é integrado à área de Ciências Humanas, "realçando seu caráter histórico e filosófico"15. Tal inclusão, no entender do documento, "contribui para o estudo da diversidade cultural religiosa na perspectiva dos direitos humanos"16. Para essa primeira versão da BNCC, o Ensino Religioso é um componente curricular "de caráter notadamente não confessional" 17 e que assume, na educação básica, a tarefa de dar acesso aos saberes e aos conhecimentos das diversas cosmovisões e tradições religiosas, que devem ser estudados a partir de pressupostos "científicos, estéticos, éticos, culturais e linguísticos"18.

Na segunda versão do documento, lançado em 2016, a primeira mudança significativa é que, agora, o Ensino Religioso se encontra em uma área própria de conhecimento, embora mantenha sua relação especial com a área de Ciências Humanas. Também se frisa "o caráter notadamente não confessional" desse componente curricular. ${ }^{19}$ Outra novidade é que se propõe que os conteúdos usados pelo Ensino Religioso sejam pautados pelas áreas do conhecimento do campo das Ciências Humanas e Sociais, "notadamente da(s) Ciência(s) da(s) Religião(ões)"20.

A terceira e última versão da BNCC foi a que gerou mais polêmica. Em sua primeira edição, o Ensino Religioso está ausente. A justificativa aparece em uma nota de rodapé, afirmando que a exclusão aconteceu para atender a LDBEN, segundo a qual a competência para regulamentar e estabelecer conteúdos é de competência dos estados e municípios. ${ }^{21}$ Entretanto, a versão que foi finalmente sancionada pelo governo reintroduz o Ensino Religioso, novamente como área do conhecimento independente, "cujas natureza e finalidades pedagógicas são distintas da confessionalidade"22. Como

14 A Base Nacional Comum Curricular foi elaborada para atender o que preceitua o artigo 26 da LDBEN: "Os currículos da educação infantil, do ensino fundamental e do ensino médio devem ter base nacional comum, a ser complementada, em cada sistema de ensino e em cada estabelecimento escolar, por uma parte diversificada, exigida pelas características regionais e locais da sociedade, da cultura, da economia e dos educandos". BRASIL. lei n 12.796, de 4 de abril de 2013. Altera a Lei ${ }^{\circ} 9.394$, de 20 de dezembro de 1996, que estabelece as diretrizes e bases da educação nacional, para dispor sobre a formação dos profissionais da educação e dar outras providências. Disponível em: < http://www.planalto.gov.br/ Ccivil_03/Ato2011-2014/2013/Lei/L12796.htm\#art1>. Acesso em: 10 mar. 2018.

15 BRASIL. Ministério da Educação. Base Nacional Curricular Comum do Ensino Básico. Brasília, 2015. p. 235. Disponível em: <goo.gl/Gj7n5N>. Acesso em: 10 mar. 2018.

16 BRASIL, 2015, p. 237.

17 BRASIL, 2015, p. 283.

18 BRASIL, 2015, p. 284.

19 BRASIL. Ministério da Educação. Base Nacional Curricular Comum do Ensino Básico. Brasília, 2016. p. 171. Disponível em: <http://movimentopelabase.org.br/wp-content/uploads/2016/05/BNCC-BOOK-WEB.pdf>. Acesso em: 10 mar. 2018.

${ }^{20}$ BRASIL, 2016, p. 170.

21 BRASIL. Ministério da Educação. Base Nacional Curricular Comum do Ensino Básico. Brasília, 2017 a. p. 25, n. 26. Disponível em: <goo.gl/DYWfvh >. Acesso em: 10 mar. 2018.

22 BRASIL. Ministério da Educação. Base Nacional Curricular Comum do Ensino Básico. Brasília, $2017 \mathrm{~b}$. p. 433. Disponível em: <http://basenacionalcomum.mec.gov.br/wp-content/uploads/2018/02/bncc-20dez-site.pdf>. Acesso em: 10 mar. 2018. 
essa é a edição aprovada da BNCC, vamos nos deter um pouco mais nos detalhes que ela apresenta sobre esse componente curricular.

Quanto aos objetivos do Ensino Religioso, a BNCC preconiza que deve:

a) Proporcionar a aprendizagem dos conhecimentos religiosos, culturais e estéticos, a partir das manifestações religiosas percebidas na realidade dos educandos.

b) Propiciar conhecimentos sobre o direito à liberdade de consciência e de crença, no constante propósito de promoção dos direitos humanos.

c) Desenvolver competências e habilidades que contribuam para o diálogo entre perspectivas religiosas e seculares de vida, exercitando o respeito à liberdade de concepções e o pluralismo de ideias, de acordo com a Constituição Federal.

d) Contribuir para que os educandos construam seus sentidos pessoais de vida a partir de valores, princípios éticos e da cidadania. ${ }^{23}$

Observe-se que, no item "a", o documento propõe uma leitura fenomenológica do conhecimento religioso ("a partir das manifestações religiosas percebidas na realidade dos educandos"). Também relaciona o Ensino Religioso com a promoção dos direitos humanos (item "b"), do diálogo (item "c") e da construção de sentidos de vida baseados em princípios éticos e de cidadania. Como veremos na segunda parte deste artigo, tais objetivos devem ser problematizados.

A versão final da BNCC manteve que o conhecimento religioso, que é o objeto de estudo do Ensino Religioso, deve ser produzido "no âmbito das diferentes áreas do conhecimento científico das Ciências Humanas e Sociais, notadamente da(s) Ciência(s) da(s) Religião(ões)", sem privilegiar nenhuma crença ou convicção, de modo a abordar tal conhecimento "com base nas diversas culturas e tradições religiosas, sem desconsiderar a existência de filosofias seculares de vida" ${ }^{24}$.

Tomando como fundamentos teóricos e pedagógicos "a interculturalidade e a ética da alteridade", a Base Nacional Comum Curricular propõe como competências específicas do Ensino Religioso:

1) Conhecer os aspectos estruturantes das diferentes tradições/movimentos religiosos e filosofias de vida, a partir de pressupostos científicos, filosóficos, estéticos e éticos.

2) Compreender, valorizar e respeitar as manifestações religiosas e filosofias de vida, suas experiências e saberes, em diferentes tempos, espaços e territórios.

3) Reconhecer e cuidar de si, do outro, da coletividade e da natureza, enquanto expressão de valor da vida.

4) Conviver com a diversidade de crenças, pensamentos, convicções, modos de ser e viver.

5) Analisar as relações entre as tradições religiosas e os campos da cultura, da política, da economia, da saúde, da ciência, da tecnologia e do meio ambiente.

${ }^{23}$ BRASIL, 2017b, p. 434.

${ }^{24}$ BRASIL, 2017b, p. 434. 
6) Debater, problematizar e posicionar-se frente aos discursos e práticas de intolerância, discriminação e violência de cunho religioso, de modo a assegurar os direitos humanos no constante exercício da cidadania e da cultura de paz..$^{25}$

Observa-se nesses itens a preocupação de consolidar, no Ensino Religioso, um caráter laico e científico (especificamente o item " 1 "), bem como de fazer dele um instrumento da promoção da tolerância e da ética. Essas são questões que tocam na dimensão epistemológica do componente curricular Ensino Religioso, como veremos a seguir.

\section{Ensino Religioso: questões epistemológicas}

A partir da atual legislação, o Ensino Religioso acentua um novo olhar epistemológico, apontando para uma prática pedagógica que privilegia a diversidade cultural e religiosa. O componente curricular Ensino Religioso é considerado parte integrante da formação básica do cidadão e da cidadã. A cidadania envolve o conhecer, o dialogar, a troca de saberes, direito e deveres. O currículo do Ensino Religioso, portanto, necessita disponibilizar o conhecimento de todas as tradições religiosas, não sendo função da escola a prática de proselitismo, adesão ou prática de uma ou outra tradição religiosa. A nova BNCC acentua:

Ao longo da história da educação brasileira, o Ensino Religioso assumiu diferentes perspectivas teórico-metodológicas, geralmente de viés confessional ou interconfessional. A partir da década de 1980, as transformações socioculturais que provocaram mudanças paradigmáticas no campo educacional também impactaram no Ensino Religioso. Em função dos promulgados ideais de democracia, inclusão social e educação integral, vários setores da sociedade civil passaram a reivindicar a abordagem do conhecimento religioso e o reconhecimento da diversidade religiosa no âmbito dos currículos escolares ${ }^{26}$.

O Ensino Religioso recebeu, a partir da nova legislação, status de componente curricular, portanto necessita articular-se a partir da escola e não de uma tradição religiosa. O Fórum Nacional Permanente do Ensino Religioso (FONAPER), como entidade civil organizada que discute a forma desse componente curricular ser ministrado há muitos anos, acentua que, assim como as outras áreas do conhecimento humano, o Ensino Religioso também necessita de um tratamento didático-pedagógico adequado, a fim de organizar os conteúdos e trabalhá-los na perspectiva de construção de conhecimentos. Os BNCC aprovados, como já foi referido, também acentuam o componente curricular Ensino Religioso nessa mesma direção.

A reflexão teórica e prática desse componente curricular tem avançado muito nos últimos anos, especialmente desde a Constituição de 1988. No entanto, ainda se

\footnotetext{
${ }^{25}$ BRASIL, 2017b, p. 435.
}

${ }^{26}$ BRASIL, 2017b, p. 433. 
convive com falta de clareza epistemológica e de práticas pedagógicas que suscitam o proselitismo e a intolerância religiosa. Em 2004, o pesquisador e professor Evaldo Luis Pauly apontou para um dilema epistemológico do Ensino Religioso. Segundo o autor:

Para a Constituição Federal de 1988, religião é direito individual (art. 5, VI) e educação, direito social (art. $6^{\circ}$ ). O art. 210, $\S 1^{\circ}$, situa o ensino religioso no espaço, ao mesmo tempo, público (escola) e privado (liberdade de consciência). Essa localização ambígua implica dilema epistemológico ${ }^{27}$.

De acordo com Pauly, a Constituição brasileira garante a religião como direito individual e a educação como direito social, situando o Ensino Religioso como um direito privado (liberdade de consciência) num espaço público, que é a escola. Nesse sentido, na percepção de Pauly, surge um dilema epistemológico. De acordo com ele, o FONAPER elaborou os PCNERS, o que foi um avanço, no entanto colocou o Transcendente ${ }^{28}$ como objeto de estudo do Ensino Religioso. Segundo Pauly: "Não parece razoável admitir a transcendência como objeto cognoscível. As experiências humanas atribuídas ao transcendente não podem ser objeto do diálogo cognoscente. O Estado democrático e de direito é laico" 29 .

Outra questão questionada por Pauly é pensar o componente curricular do Ensino Religioso para o exercício da cidadania. O autor coloca: "A justificativa de que o ensino religioso é um componente curricular porque integra a formação para a cidadania é falsa. A suposição de que uma pessoa religiosa seja melhor, igual ou pior cidadã em razão de sua crença, caracteriza clara discriminação" ${ }^{\text {"30 }}$. Outra questão levantada pelo mesmo autor, a partir de Thales de Azevedo, diz respeito a ensinar moral no Ensino Religioso. "Justificar o ensino religioso pela necessidade de propiciar formação moral aos educandos também é falso. Nesse caso, ele seria uma 'religião civil', segundo a qual os princípios transcendentes teriam a função precípua de consolidar a solidariedade social”31. Nesse sentido, Osvaldo Luiz Ribeiro também afirma que o Ensino Religioso não pode ser educação moral, mas deve ser:

[...] espaço de empoderamento crítico do cidadão e da cidadã ali encaminhados [...] e que dá a medida em que é informado - sempre - criticamente - sobre os processos materiais e sociais de criação, nesse caso dos valores, sobre os quais, portanto coloca-se a sociedade na sua negociação de transformação históricas ${ }^{32}$.

27 PAULY, Evaldo Luis. O dilema epistemológico do ensino religioso. Revista Brasileira de Educação, n. 27, p. 173, 2004. Disponível em: <http://www.scielo.br/pdf/rbedu/n27/n27a11.pdf >. Acesso em: 15 dez. 2017.

28 FÓRUM NACIONAL PERMANENTE DO ENSINO RELIGIOSO. Parâmetros Curriculares Nacionais - Ensino Religioso. São Paulo: Mundo Mirim, 2009. p. 12.

${ }^{29}$ PAULY, 2004, p. 174.

${ }^{30}$ PAULY, 2004, p. 174.

31 AZEVEDO, 1981, p. 72 apud PAULY, 2004, p. 174.

${ }^{32}$ RIBEIRO, Osvaldo Luiz. "Não se justifica moralmente" - uma crítica ao modelo de ensino religioso como educação moral. In: SANTOS, Francisco de Assis Souza; GONÇALVES, José Mário; RIBEIRO, Osvaldo Luiz (Orgs.). Ciências das religiões aplicadas: interfaces de uma ciência-profissão. Vitória: Unida, 2014. p. 197. 
Uma educação crítica questiona, constantemente, os valores morais, religiosos e culturais sobre os quais a sociedade, historicamente, foi construída. Pauly encerra o seu artigo, afirmando:

Apesar da crítica aqui apresentada, a lei $\mathrm{n}^{\circ} 9.475$ acabou com a possibilidade de as igrejas e religiões controlarem o ensino religioso na escola pública. Por essa lei, pela segunda vez na história republicana brasileira, elas perderam o controle sobre currículo, formação e seleção do corpo docente de ensino religioso. A partir de agora, as igrejas que quiserem influir no ensino religioso podem fazê-lo como entidades da sociedade civil inseridas na comunidade escolar, e pela conquista do apoio de docentes e discentes desse ensino. A resolução do dilema epistemológico desta disciplina se fará pela capacidade de mobilização autônoma da comunidade escolar e acadêmica capaz de justificar uma ética republicana e de fundamentar uma epistemologia científica para o ensino religioso ${ }^{33}$.

É necessário, portanto, deixar claro que o objeto de estudo do Ensino Religioso não é o Transcendente, nem o estudo das religiões, tampouco o ensino dos valores ético-morais. O novo foco do Ensino Religioso é o estudo do fenômeno religioso, articulando-se a partir da escola, que é um espaço multicultural e multirreligioso. Segundo Lilian Blanck de Oliveira:

A fenomenologia das religiões evidenciou a existência de uma relação intrínseca entre cultura e religião, a ponto de a ignorância sobre tal relação poder tornar o pesquisador inapto para compreender o fenômeno religioso. [...] Atualmente, considera-se como marco referencial a concepção de que o fenômeno religioso se manifesta em uma cultura. É a cultura que marca profundamente a maneira de ser e viver do ser humano ${ }^{34}$.

O BNCC, nesse sentido, acentua, como já referido, que o conhecimento religioso, objeto da área de Ensino Religioso, é produzido no âmbito das diferentes áreas do conhecimento científico das Ciências Humanas e Sociais, notadamente da(s) Ciência(s) da(s) Religião(ões).

Essas Ciências investigam a manifestação dos fenômenos religiosos em diferentes culturas e sociedades enquanto um dos bens simbólicos resultantes da busca humana por respostas aos enigmas do mundo, da vida e da morte. De modo singular, complexo e diverso, esses fenômenos alicerçaram distintos sentidos e significados de vida e diversas ideias de divindade(s), em torno dos quais se organizaram cosmovisões, linguagens, saberes, crenças, mitologias, narrativas, textos, símbolos, ritos, doutrinas, tradições, movimentos, práticas e princípios éticos e morais. Os fenômenos religiosos em suas múltiplas manifestações são parte integrante do substrato cultural da humanidade. Cabe ao Ensino Religioso tratar os conhecimentos religiosos a partir de pressupostos éticos e científicos, sem privilégio de nenhuma crença ou conviç̧ão. Isso implica abordar esses

33 PAULY, 2004, p. 174.

${ }^{34}$ OLIVEIRA, Lilian Blanck de et al. Ensino religioso no ensino fundamental. São Paulo: Cortez, 2007. p. 66-67. 
conhecimentos com base nas diversas culturas e tradições religiosas, sem desconsiderar a existência de filosofias seculares de vida. ${ }^{35}$

A escola pública e a privada são espaços de vivência da pluralidade cultural e religiosa. Docentes e discentes trazem consigo diferentes experiências culturais e religiosas. Na escola, convive-se "com colegas e alunos/alunas pertencentes à coletividade, a etnias que têm compreensões diversas do mundo, da vida, das relações sociais. Têm [...] símbolos, rituais, crenças e valores diferenciados" ${ }^{36}$. Segundo Wagner Lopes Sanchez:

A descoberta da alteridade, portanto, é, antes de tudo, a experiência da diferença. Este é o núcleo central das culturas, a existência das diferenças. A consciência da existência da diferença possibilita à pessoa e à cultura estabelecer, em meio às diversas contradições e contradições, a sua identidade. [...]

Uma das aproximações possíveis do conceito de cultura é justamente aquela que compreende cultura como diferença específica dos grupos e povos nas suas relações consigo mesmos (identidade) e com as outras culturas [...]. Dessa forma, o que define a cultura de um grupo ou povo é a diferença construída histórica e coletivamente. ${ }^{37}$

É importante deixar claro que a diferença não é sinônimo de desigualdade. Como afirma Ana Célia da Silva, é função do/a professor/a "ensinar que a diferença pode ser bela, que a diversidade é enriquecedora e não é sinônimo de desigualdade, é um dos passos para a reconstrução da autoestima, do autoconceito, da cidadania e da abertura para o acolhimento dos valores das diversas culturas presentes na sociedade" $" 38$. A diversidade aponta para diferentes expressões da cultura.

Torna-se importante ter claro o que se entende por cultura. De acordo com Marilena Chauí, atualmente não é mais possível falar "em Cultura no singular, mas de culturas no plural, pois as leis, os valores, as crenças, as práticas e instituições variam de formação social para formação social" ${ }^{39}$. Entende-se, portanto, cultura como "a maneira pela qual os humanos se humanizam por meio de práticas que criam a existência social, econômica, política, religiosa, intelectual e artística" 40 . A cultura envolve um conjunto de elementos que abarca os modos de vida de um grupo humano. Nesse sentido a religião também é um traço da cultura de um determinado povo. A Declaração da UNESCO sobre Políticas Culturais de 1982 concebe a cultura como:

35 BRASIL, 2017b, p. 434.

36 ARROYO, Miguel G. Assumir nossa diversidade cultural. Revista de Educação - AEC, Brasília, v. 25. n. 98, p. 46, jan./mar. 1996.

37 SANCHEZ, Wagner Lopes. Pluralismo religioso: As religiões no mundo atual. São Paulo: Paulinas, 2005. p. 87.

38 SILVA, Ana Célia da. A Desconstrução da Discriminação no Livro Didático. In: MUNANGA, Kabengele. Superando o racismo na escola. 2. ed. rev. Brasília: Ministério da Educação, Secretaria de Educação Continuada, Alfabetização e Diversidade, 2005. p. 31.

39 CHAUÍ, Marilena. Convite à filosofia. 4. ed. São Paulo: Ática, 1995. p. 295.

40 CHAUÍ, 1995, p. 295. 
[...] o conjunto dos traços distintivos, espirituais e materiais, intelectuais e afetivos que caracterizam uma sociedade ou um grupo social e que abarca, para além das artes e das letras, os modos de vida, os direitos fundamentais do ser humano, os sistemas de valores, as tradições e as crenças ${ }^{41}$.

A Constituição Federal de 1988 apresenta no seu Art. 216 o conceito de patrimônio cultural:

Art. 216 - Constituem patrimônio cultural brasileiro os bens de natureza material e imaterial, tomados individualmente ou em conjunto, portadores de referência à identidade, à ação, à memória dos diferentes grupos formadores da sociedade brasileira nos quais se incluem: I - as formas de expressão; II - os modos de criar, fazer e viver; $[. . .]^{42}$.

O conceito de patrimônio cultural colocado pela constituição abrange os bens de natureza material e imaterial, isto é, inclui formas de expressão, os modos de criar, fazer e viver. A religião, portanto, também faz parte de um modo de viver. Nesse sentido, é importante perceber as tradições religiosas sempre no plural, pois essas também estão se modificando constantemente. Desta forma, podemos ver a própria cultura como uma construção sócio-histórica, apenas uma possibilidade em meio a tantas outras. De acordo com os Parâmetros Curriculares Nacionais, publicados em 1997:

As culturas são produzidas pelos grupos sociais ao longo das suas histórias, na construção de suas formas de subsistência, na organização da vida social e política, nas suas relações com o meio e com outros grupos, na produção de conhecimentos etc. A diferença entre culturas é fruto da singularidade desses processos em cada grupo social ${ }^{43}$.

Nesse sentido, os Parâmetros Curriculares Nacionais apontam para a pluralidade cultural brasileira como fruto do desenvolvimento do processo histórico:

A pluralidade cultural existente no Brasil é fruto de um longo processo histórico de interação entre aspectos políticos e econômicos, no plano nacional e internacional. Esse processo apresenta-se como uma construção cultural brasileira altamente complexa, historicamente definida e redefinida continuamente em termos nacionais, apresentando características regionais e locais. Coexistem aqui culturas singulares, ligadas a identidades de origem de diferentes grupos étnicos e culturais. Essa composição cultural tem se caracterizado por plasticidade e permeabilidade, incorporando em seu cotidiano a

${ }^{41}$ UNESCO. Organização das Nações Unidas para a Educação, a Ciência e a Cultura. Relatório Mundial da UNESCO. Investir na diversidade cultural e no dialogo intercultural. Paris, 2009. p. 4. Disponível em: $<$ http://unesdoc.unesco.org/images/0018/001847/184755por.pdf>. Acesso em: 20 fev. 2018.

42 BRASIL. Constituição da República Federativa do Brasil: texto constitucional promulgado em 5 de outubro de 1988, com as alterações determinadas pelas Emendas Constitucionais de Revisão nos 1 a 6/94, pelas Emendas Constitucionais nos 1/92 a 91/2016 e pelo Decreto Legislativo no 186/2008. Brasília: Senado Federal, Coordenação de Edições Técnicas, 2016. p. 126.

43 BRASIL. Secretaria de Educação Fundamental. Parâmetros curriculares nacionais: pluralidade cultural, orientação sexual / Secretaria de Educação Fundamental. Brasília: MEC/SEF, 1997. p. 19. Disponível em: <http://portal.mec.gov.br/seb/arquivos/pdf/livro101.pdf>. Acesso em: 10 mar. 2017. 
criação e recriação das culturas de todos esses povos, sem diluí-las, ao mesmo tempo em que permite seu entrelaçamento. Nesse entrelaçamento de influências recíprocas, configuram-se a permanente elaboração e redefinição da identidade nacional, em sua complexidade ${ }^{44}$.

O reconhecimento da pluralidade cultural e religiosa é fundamental para a constante redefinição da identidade nacional e ela passa pelo processo educativo que se realiza no ambiente escolar. Nesse sentido, a última versão do BNCC, disponibilizada em 2018, coloca que o Ensino Religioso no ensino fundamental adota

a pesquisa e o diálogo como princípios mediadores e articuladores dos processos de observação, identificação, análise, apropriação e ressignificação de saberes, visando ao desenvolvimento de competências específicas. Dessa maneira, busca problematizar representações sociais preconceituosas sobre o outro, com o intuito de combater a intolerância, a discriminação e a exclusão ${ }^{45}$.

Objetiva-se, portanto, através da pesquisa e do diálogo com os/as estudantes, ressignificar saberes, tendo como meta o combate da intolerância religiosa, da discriminação e da exclusão. Percebe-se que a nova BNCC busca fomentar um

Ensino Religioso que busca construir, por meio do estudo dos conhecimentos religiosos e das filosofias de vida, atitudes de reconhecimento e respeito às alteridades. Trata-se de um espaço de aprendizagens, experiências pedagógicas, intercâmbios e diálogos permanentes, que visam ao acolhimento das identidades culturais, religiosas ou não, na perspectiva da interculturalidade, direitos humanos e cultura da paz. Tais finalidades se articulam aos elementos da formação integral dos estudantes, na medida em que fomentam a aprendizagem da convivência democrática e cidadã, princípio básico à vida em sociedade ${ }^{46}$.

A nova BNCC busca situar o Ensino Religioso de acordo com o artigo 33 da LDB LDBEN (Lei 9.394/96), conforme a redação dada pela Lei 9.475/97, tendo como objetivo a convivência democrática cidadã, a partir do acolhimento da diversidade cultural, na perspectiva pedagógica-epistemológica da interculturalidade, dos direitos humanos e da cultura da paz. No entanto, torna-se importante frisar que esses objetivos somente serão alcançados com a formação de professores/as em licenciatura em Ensino Religioso. Esse é um passo fundamental para superar os desvios epistemológicos na realização do Ensino Religioso nas escolas públicas brasileiras.

\footnotetext{
44 BRASIL, 1997, p. 24.

${ }^{45}$ BRASIL, 2017b, p. 435.

${ }^{46}$ BRASIL, 2017b, p. 435.
} 


\section{Conclusão}

Percebemos na nova BNCC, lançada para as escolas públicas em 2018, avanços na reflexão em relação ao componente curricular Ensino Religioso. No entanto, é necessário realçar que o texto final aprovado foi alvo de muitas disputas, pois, como refletimos, a própria legislação apresenta contradições. Concluímos, portanto, que para o componente curricular Ensino Religioso conseguir sair em definitivo das contradições e impasses políticos e epistemológicos nos quais se encontra, faz-se necessária uma mudança na atual legislação, no sentido de equipará-lo aos demais componentes curriculares da educação básica, definindo suas diretrizes curriculares (o que a BNCC parcialmente faz), estabelecendo com clareza os critérios de formação docente (licenciatura em Ensino Religioso) e afirmando com clareza seu caráter não confessional, não catequético e não proselitista. Necessitamos sempre de novo afirmar a importância da construção do conhecimento religioso, objetivando a superação da intolerância religiosa, na descoberta bela da alteridade, no respeito às diferenças e na afirmação da riqueza histórica da pluralidade e diversidade religiosa brasileira.

\section{Referências}

ARROYO, Miguel G. Assumir nossa diversidade cultural. Revista de Educação - AEC, Brasília, v. 25, n. 98, p. 42-57, jan./mar. 1996.

BRASIL. Constituição da República Federativa do Brasil: texto constitucional promulgado em 5 de outubro de 1988, com as alterações determinadas pelas Emendas Constitucionais de Revisão nos 1 a 6/94, pelas Emendas Constitucionais nos 1/92 a 91/2016 e pelo Decreto Legislativo no 186/2008. Brasília: Senado Federal, Coordenação de Edições Técnicas, 2016.

BRASIL. Lei n ${ }^{\circ}$ 9.475, de 22 de julho de 1997. Dá nova redação ao art. 33 da Lei n 9.394, de 20 de dezembro de 1996, que estabelece as diretrizes e bases da educação nacional. Disponível em: <http://www.planalto.gov.br/ccivil_03/leis/L9475.htm>. Acesso em: 10 mar. 2018.

BRASIL. Decreto ${ }^{\circ}$ 7.107, de 11 de fevereiro de 2010. Promulga o Acordo entre o Governo da República Federativa do Brasil e a Santa Sé relativo ao Estatuto Jurídico da Igreja Católica no Brasil, firmado na Cidade do Vaticano, em 13 de novembro de 2008. Disponível em: $<$ http://www. planalto.gov.br/ccivil_03/_ato2007-2010/2010/decreto/d7107.htm>. Acesso em: 10 mar. 2018. BRASIL. Supremo Tribunal Federal. Ação direta de inconstitucionalidade n ${ }^{\circ}$ 4439/DF - Distrito Federal. Relator: Ministro Roberto Barroso. Petição inicial, 30 jul. 2010. Disponível em: $<$ http:// redir.stf.jus.br/estfvisualizadorpub/jsp/consultarprocessoeletronico/ConsultarProcessoEletronico. jsf?seqobjetoincidente $=3926392>$. Acesso em: 10 mar. 2018

BRASIL. Supremo Tribunal Federal. Ação direta de inconstitucionalidade no 4439/DF - Distrito Federal. Relator: Ministro Roberto Barroso. Petição inicial, 30 jul. 2010. Disponível em: <http:// redir.stf.jus.br/estfvisualizadorpub/jsp/consultarprocessoeletronico/ConsultarProcessoEletronico. jsf?seqobjetoincidente=3926392 > . Acesso em: 10 mar. 2018 .

BRASIL. Supremo Tribunal Federal. Ação direta de inconstitucionalidade n ${ }^{\circ}$ 4439/DF - Distrito Federal. Relator: Ministro Roberto Barroso. Certidão de Julgamento, 27 set. 2017. Disponível em: $<$ http://redir.stf.jus.br/estfvisualizadorpub/jsp/consultarprocessoeletronico/ConsultarProcessoEletronico.jsf? seqobjetoincidente $=3926392>$. Acesso em: 10 mar. 2018.

BRASIL. Lei $\mathrm{n}^{\circ}$ 13.415, de 16 de fevereiro de 2017. Altera as Leis nos 9.394, de 20 de dezembro de 1996, que estabelece as diretrizes e bases da educação nacional, e 11.494, de 20 de junho 2007, que regulamenta o Fundo de Manutenção e Desenvolvimento da Educação Básica e de 
Valorização dos Profissionais da Educação, a Consolidação das Leis do Trabalho - CLT, aprovada pelo Decreto-Lei no 5.452, de $1^{\circ}$ de maio de 1943, e o Decreto-Lei ${ }^{\circ} 236$, de 28 de fevereiro de 1967; revoga a Lei ${ }^{\circ} 11.161$, de 5 de agosto de 2005; e institui a Política de Fomento à Implementação de Escolas de Ensino Médio em Tempo Integral. Disponível em: $<$ http://www. planalto.gov.br/ccivil03/Ato2015-2018/2017/Lei/L13415.htm\#art7>. Acesso em: 10 mar. 2018. BRASIL. Lei $n^{\circ} 12.796$, de 4 de abril de 2013. Altera a Lei $n^{\circ} 9.394$, de 20 de dezembro de 1996, que estabelece as diretrizes e bases da educação nacional, para dispor sobre a formação dos profissionais da educação e dar outras providências. Disponível em: $<$ http://www.planalto. gov.br/Ccivil03/Ato2011-2014/2013/Lei/L12796.htm\#art1>. Acesso em: 10 mar. 2018.

BRASIL. Ministério da Educação. Base Nacional Curricular Comum do Ensino Básico. Brasília, 2015. Disponível em: <goo.gl/Gj7n5N>. Acesso em: 10 mar. 2018.

BRASIL. Ministério da Educação. Base Nacional Curricular Comum do Ensino Básico. Brasília, 2016. Disponível em: <http://movimentopelabase.org.br/wp-content/uploads/2016/05/BNCC-BOOK-WEB.pdf>. Acesso em: 10 mar. 2018.

BRASIL. Ministério da Educação. Base Nacional Curricular Comum do Ensino Básico. Brasília, 2017a. Disponível em: <goo.gl/DYWfvh >. Acesso em: 10 mar. 2018.

BRASIL. Ministério da Educação. Base Nacional Curricular Comum do Ensino Básico. Brasília, 2017b. Disponível em: <http://basenacionalcomum.mec.gov.br/wp-content/uploads/2018/02/ bncc-20dez-site.pdf $>$. Acesso em: 10 mar. 2018.

BRASIL. Secretaria de Educação Fundamental. Parâmetros curriculares nacionais: pluralidade cultural, orientação sexual / Secretaria de Educação Fundamental. Brasília: MEC/SEF, 1997. p. 19. Disponível em: <http://portal.mec.gov.br/seb/arquivos/pdf/livro101.pdf >. Acesso em: 10 mar. 2017.

CHAUÍ, Marilena. Convite à filosofia. 4. ed. São Paulo: Ática, 1995.

FÓRUM NACIONAL PERMANENTE DO ENSINO RELIGIOSO. Parâmetros Curriculares Nacionais - Ensino Religioso. São Paulo: Mundo Mirim, 2009.

PAULY, Evaldo Luis. O dilema epistemológico do ensino religioso. Revista Brasileira de Educação, n. 27, 2004. Disponível em: <http://www.scielo.br/pdf/rbedu/n27/n27a11.pdf > Acesso em: 15 dez. 2017.

OLIVEIRA, Lilian Blanck de et al. Ensino religioso no ensino fundamental. São Paulo: Cortez, 2007.

RIBEIRO, Osvaldo Luiz. "Não se justifica moralmente" - uma crítica ao modelo de ensino religioso como educação moral. In: SANTOS, Francisco de Assis Souza; GONÇALVES, José Mário; RIBEIRO, Osvaldo Luiz (Orgs.). Ciências das religiões aplicadas: interfaces de uma ciência-profissão. Vitória: Unida, 2014.

SILVA, Ana Célia da. A Desconstrução da Discriminação no Livro Didático. In: MUNANGA, Kabengele. Superando o racismo na escola. 2. ed. rev. Brasília: Ministério da Educação, Secretaria de Educação Continuada, Alfabetização e Diversidade, 2005.

SANCHEZ, Wagner Lopes. Pluralismo religioso: As religiões no mundo atual. São Paulo: Paulinas, 2005.

UNESCO. Organização das Nações Unidas para a Educação, a Ciência e a Cultura. Relatório Mundial da UNESCO. Investir na diversidade cultural e no dialogo intercultural. Paris, 2009. Disponível em: < http://unesdoc.unesco.org/images/0018/001847/184755por.pdf > . Acesso em: 20 fev. 2018. 